UDK: 373.2.011.3-051

Pregledni rad

\title{
SUVREMENI ODGOJITELJ KAO PEDAGOŠKI PRAKTIČAR
}

\section{Željka Pintar}

Dječji vrtić Kustošija, Zagreb

Republika Hrvatska

zeljka.pint@gmail.com 


\section{SAŽETAK}

Ushvaćanjuodgojiteljakaopedagoškogpraktičarapotrebnojepoćiod razmatranja suvremenog statusa pedagogije kao znanosti, sobzirom na pretpostavku kako je upravo ona temelj usmjeravanja odgojno-obrazovnog praktičnog djelovanja odgojitelja. Rad se osvrće na aktualan status odgojno-obrazovnih djelatnika u ustanovama ranog $i$ predškolskog odgoja i obrazovanja te stručne zahtjeve koji se pred njih postavljaju. Upućuje se na znanstvenu (ne)autonomnost pedagogije. Ističe se uloga odgojitelja u razvoju odgojno-obrazovnog sustava predškolskog odgoja. Na temelju razumijevanja aktualne pozicije pedagogije i shvaćanja zahtjeva upućenih stručnim djelatnicima u predškolskim ustanovama, razmatra se koncept inicijalnog obrazovanja odgojitelja djece rane i predškolske dobi te se tematizira njegova adekvatnost u odnosu na stručan profil suvremenih odgojitelja i potrebu afirmacije njihove pedagoške djelatnosti.

Ključne riječi: odgojitelj djece rane i predškolske dobi, pedagoški praktičar, suvremene ustanove ranog i predškolskog odgoja i obrazovanja. 


\section{UVOD}

Suvremena pedagoška paradigma ranog i predškolskog odgoja i obrazovanja dominantno se zasniva na konstruktivizmu, psihološkoj spoznajnoj teoriji. Pojedini autori uočavaju kako pedagogiji nedostaju izvorna znanja i autentične spoznaje (Sekulić-Majurec, 2007). Smatra se kako suvremena pedagogija nekritički preuzima spoznaje srodnih znanosti i kako se, u odnosu na njih, sporije obogaćuje novim saznanjima. Razmotri li se suvremeni razvoj pedagogije i razina njezinih autentičnih spoznaja kao autonomne znanosti, i usporedi li ju se s njoj srodnim disciplinama, psihologijom i sociologijom, zaključuje se kako se ona ne razvija i ne obogaćuje novim spoznajama jednakim intenzitetom kao spomenute znanosti (Sekulić-Majurec, 2007).

Pojedini autori (poput Slunjski, 2016) navode kako razvoj novih znanja $i$ novih sustava vrijednosti i uvjerenja obvezuje odgojno-obrazovni sustav na uvođenje inovacija, a odgojno-obrazovne ustanove i odgojitelje na razvoj novih pristupa, novih procesa i nove prakse. Svijet u kojem žive današnja djeca mijenja se četiri puta brže nego odgojno-obrazovne ustanove, pa se slijedom toga zaključuje kako je opravdano reći da je permanentno mijenjanje ustanova za rani i predškolski odgoj i obrazovanje, kako bi održale korak s vremenom promjene u kojem djeluju, postalo ultimativni imperativ (Dryden i Vos, 2001, prema Slunjski, 2016). Odgojno-obrazovne ustanove koje se ne razvijaju brže od ostalih organizacija već u startu za njima kasne (Slunjski, 2016). Naglašava se kako burne političke, kulturne, gospodarske i demografske promjene zahtijevaju bitno promijenjen dječji vrtić i inovirani pristup edukaciji odgojitelja (Mlinarević, 2000).

No, brza promjena suvremenih odgojno-obrazovnih ustanova i djelovanja stručnog kadra trebala bi podrazumijevati jednako brz razvoj pedagogijskih spoznaja jer je upravo za njih razložno očekivati da su osnova odgojiteljevog stručnog angažmana. Kako se napominje (Palekčić, 2013), tek rastom pedagogijske teorijske spoznaje, stvaraju se uvjeti za poboljšanje kvalitete praktičnog pedagoškog djelovanja. U suprotnom, postavlja se pitanje na kojim se i čijim (znanstvenim) spoznajama zasniva i utemeljuje stručan rad odgojitelja. Pristup u kojem se praksa odgojitelja dominantno zasniva na praćenju društvenih gospodarskih i ekonomskih promjena nije afirmativan za pedagogiju kao znanost, ni za odgojitelja kao pedagoškog stručnjaka.

Razvoj obrazovanja suvremenog odgojitelja u specifičnom je fokusu nekih autora (poput Mendeš, 2018). Ističu se brojniizazovi skojima je suočeno suvremeno obrazovanje odgojitelja. Napominje se kako je unutar formalnog obrazovanja budućih odgojitelja premalo prostora za formiranje, građenje i razvijanje 
istraživačkih kompetencija koje su nužne za kasnije autonomno strukturiranje i restrukturiranje pedagoške prakse (Šagud, 2011). Jasno je kako je cilj inicijalnog obrazovanja odgojitelja autonomni djelatnik koji oblikuje odgojno-obrazovnu praksu. Autonoman je onaj odgojitelj koji je neovisan o autoritetima, a neovisnost temelji na visokoj razini profesionalne kompetencije koja mu omogućuje kreaciju programa i njegovo kreativno ostvarivanje (Mlinarević, 2000). Ukoliko odgojitelj imitira naučene modele ponašanja, ako je ovisan o „receptima“ i autoritetima, on nije dosegao zadovoljavajuću razinu autonomije (Mlinarević, 2000). U kompetencijskom pristupu obrazovanju odgojitelja građenje i razvijanje njegovih kompetencija ne temelji se isključivo na uvježbanim postupcima i obrascima ponašanja (Šagud, 2011).

No, unatoč tome što se autonomni odgojitelj deklarira kao cilj njemu usmjerenog obrazovanja, njegovu profesionalnu neovisnost potrebno je jasno kontekstualizirati. Autonomni odgojitelj neovisan je od autoriteta. No ne možemo zanemariti da odgojitelj, gradeći svoju kompetentnost inicijalnim obrazovanjem, uvažava stajališta određenih autora, prihvaća tumačenje određenih znanstvenih promišljanja $\mathrm{i}$ istraživanja te, najvažnije, usvaja stavove aktualne pedagoške paradigme kao nužno ispravne pedagoške istine.

Autori pojašnjavaju kako je autonoman odgojitelj kreativan - autonomnih misli, inicijativan, intrinzično motiviran, slobodan i kritički promišljajuć (Ozimec, 1996, prema Tischler, 2007). Osobito je važno promotriti obilježje odgojitelja kao kritički promišljajućeg pedagoškog djelatnika. Odgojiteljevo je djelovanje, naime, omeđeno nacionalnim dokumentima vezanima uz odgoj i obrazovanje kojima se ističu društvena očekivanja od pedagoškog sustava. Iako se deklarativno učitelje i odgojitelje proglašava ravnopravnim sustvarateljima obrazovne politike, zamjećuje se kako je u praksi njihovo sudjelovanje nedostatno (Jukić, Reić-Ercegovac, 2008). Konkretna provedba odgojiteljevog rada s djecom i njegov profesionalni razvoj određen je, osim uputama raznih društvenih institucija čiji su oni izvršitelji, i materijalnim sredstvima i uvjetima rada u konkretnim predškolskim ustanovama, što znatno omeđuje slobodu njihovog djelovanja (Jukić, Reić-Ercegovac, 2008). Uzimajući navedeno $\mathrm{u}$ obzir, kritički promišljajući, autonoman i kreativan odgojitelj mogao bi biti onaj koji je aktualan društveni kontekst i preferiran pedagoški koncept slobodan kritički propitivati, a pretpostavka toga je demokratski orijentirana odgojno-obrazovna organizacija i društvo razvijene demokracije koje dozvoljava razmatranje vlastitih postavki. Suvremene odgojitelje upućuje se kako je osnovna kompetencija koju trebaju kontinuirano razvijati samorefleksivnost koja im omogućuje bolje razumijevanje vlastite pedagoške prakse i osvješćivanje kvalitete vlastitih odgojno-obrazovnih intervencija u radu s djecom (Slunjski i sur., 
2006). Ipak, uz potrebu razvoja odgojiteljeve stručne introspektivnosti koja vodi do samokritičnosti, potrebno je naglasiti važnost njegove analitičnosti kojom opaža značajke općeg društvenog konteksta i znanstvenog koncepta koji određuju pristup odgoju i obrazovanju u određenoj zajednici. Na kritičko preispitivanje navedenih čimbenika, suvremeni odgojitelji trebaju biti poticani već vlastitim obrazovanjem.

\section{ZNANSTVENA PEDAGOGIJA I PEDAGOŠKA PRAKSA}

Suvremeni odgojitelji unapređuju pedagošku praksu njenim mijenjanjem. Promjene su, promatrano u nedavnoj hrvatskoj povijesti, često uvjetovane društveno-povijesnim kontekstom. Tako se nakon socijalističkog perioda i njemu pripadnog Programa odgojno - obrazovnog rada u dječjem vrtiću (1979), ostvarivanjem samostalne demokratske Republike Hrvatske, pedagoška nastojanja uobličavaju Programskim usmjerenjem odgoja i obrazovanja predškolske djece (1991). Pripremom Hrvatske za ulazak u Europsku uniju, odgojno-obrazovni koncept usklađuje se s europskim predloškom, pa se tako osmišljava Nacionalni okvirni kurikulum za rani i predškolski odgoj $i$ obrazovanje te opće obvezno $i$ srednjoškolsko obrazovanje (2011). Ipak, pojedini autori zamjećuju kako promjene koje bi se trebale provesti u odgojno-obrazovnom predškolskom sustavu često ne uspijevaju, a naglašava se kako je osnovni razlog tome praktičarevo nerazumijevanje fenomenologije promjene (Slunjski, 2016, 13). Njihovo neshvaćanje ogleda se u činjenici da uglavnom promjenu doživljavaju posve različito od načina na koji je njezini kreatori zamisle i na koji očekuju da će se ona u praksi provesti (Fullan, 1991, prema Slunjski, 2016, 13). Navedeno, međutim, i nije začuđujuće jer je sasvim očekivano da se idejno-teorijski koncept treba prilagoditi mogućnostima i logici životne realnosti. Nije niti zanemarivo jesu li promjene koje se zahtijevaju u odgojno-obrazovnom sustavu (samo) društveno-politički generirane ili su primarno uvjetovane pedagogijskim razvojem.

Pojedini autori navode kako je u kontekstu razvoja vrtića, osobito nakon stupanja na snagu Nacionalnog kurikuluma za rani i predškolski odgoj i obrazovanje (2015), na vidjelo izašla velika razlika u spremnosti odgojitelja na angažirano i predano sudjelovanje u tom procesu (Slunjski, 2016). Razlike u razini odgojiteljevog angažmana u procesu razvoja ustanova potencijalno proizlaze iz odgojiteljevog rada u privatnom ili gradskom vrtiću. Odgojitelji privatnih vrtića spremniji su osigurati višu kvalitetu odgojno-obrazovnog procesa, zbog viših standarda vezanih uz selektivnost kadra (Slunjski, 2016, 69). Oprečno navedenom, drugi autori napominju kako je upravo za hrvatske privatne škole tipična odgojna problematika razmaženih učenika (Kolak, 2015, 162). 
Odgojitelji koji ne pokazuju velik angažman $\mathrm{u}$ ostvarivanju promjena predškolskih ustanova često iznose velik broj djece u skupini kao argument za nerazvijanje prakse (Slunjski, 2016, 69). No, dok neki autori odgojiteljevo zamjećivanje broja djece u skupini navode kao njegov argument za nerazvijanje prakse, istovremeno, pozivajući se na rezultate istraživanja, drugi autori utvrđuju kako je za učinak pohađanja predškolskih ustanova na dječji socijalni razvoj važna kvaliteta procesa (Baran, 2013). Pritom kvalitetu procesa značajno određuje broj djece u skupni i obrazovanje odgojitelja. Što je broj djece u skupini manji, djeca iskazuju više prosocijalnih ponašanja i pozitivnih aktivnosti s vršnjacima te su sigurno privrženi odgojiteljima (CFMP, 2003 prema Baran, 2013). I u poticanju kognitivnog razvoja djece navodi se važnost kognitivno usmjerenog kurikuluma i veličine grupe (Baran, 2013). Opisujući organizacijsko-materijalne karakteristike predškolskog sustava u socijalističkom razdoblju u Hrvatskoj spominje se nedostatak prostornih kapaciteta, prekapacitirane odgojne skupine, slaba opremljenost vrtića igračkama i didaktičkim sredstvima, neujednačen i neadekvatan način financiranja (Lipovac, 1985, prema Baran i sur., 2011). Uzrok tadašnjeg pristupa odgojno-obrazovnim ustanovama jest činjenica da je socijalna funkcija dječjeg vrtića dominirala nad odgojno-obrazovnom (Kunstek, 1991, prema Baran i sur., 2011). Ukoliko u suvremenom društvu zajednica predviđa nove zahtjeve koje usmjerava predškolskim ustanovama, očekivano je da za navedene osigura i potrebne organizacijsko-materijalne prilike. Ukazivanje suvremenih odgojitelja na nepovoljne značajke konteksta u kojemu se provodi odgojno-obrazovni rad neopravdano je karakterizirati kao njihovu nesklonost promijeni, stručnu inertnost i profesionalnu nezainteresiranost.

Zamjetno je kako se tumačenje razloga neučinkovitosti pojedinih odgojnoobrazovnih mjera učestalo pripisuje osobno odgojitelju, često njegovoj implicitnoj pedagogiji. Navodi se kako u temeljima odgojiteljeve prakse stoji njegova osobna teorija o djetetu i dječjem vrtiću, mogućnostima učenja i poučavanja, odgoja i obrazovanja u institucionalnom kontekstu, odnosno njegova implicitna pedagogija (Miljak, 1996). Objašnjava se kako implicitna pedagogija djeluje na strukturiranje vremena i prostora, izbor materijala i aktivnosti te narav interakcije odrasli-dijete (Babić i sur., 1997). I u javnoj percepciji odgojiteljske djelatnosti, jednako kao i u stručnoj, vlada mišljenje kako je odgojiteljev pedagoški angažman primarno određen njegovim ljudskim kvalitetama, više nego stručno-metodičkim znanjima i vještinama (Lučić, 2007, prema Jukić, Reić-Ercegovac, 2008). Mišljenje da je odgojiteljev stručni angažman presudno ovisan o njegovim osobnim karakteristikama i privatnim teorijama o odgoju i obrazovanju obespravlja odgojitelja kao obrazovanog, stručno osposobljenog profesionalca čije se praktično djelovanje bazira na znanstvenim, a ne (samo) osobnim spoznajama. 
Iako se predlaže da problem provedbe koncepata koji se odgojiteljima predlažu proizlazi iz odgojiteljeve nesklonosti promjenama i njihovom nerazumijevanju fenomenologije promjene, važno je razmotriti i karakter samih promjena koje se nalažu suvremenim odgojiteljima. Suvremena paradigma ranog i predškolskog odgoja i obrazovanja zasniva se na konstruktivističkom pristupu učenju. Može li se konstruktivizam kao teorija učenja shvatiti i tumačiti kao teorija poučavanja? U tom su pitanju mišljenja didaktičara podijeljena, pa dok jedni prihvaćaju konstruktivizam kao novu paradigmu u didaktici, drugi ističu ograničenja konstruktivističkih modela (Jukić, 2013). Zagovaratelji konstruktivizma nisu znanstveno dokazali mogućnost izvođenja didaktičkih aranžmana iz spoznajne teorije, odnosno zanemaruju kako se didaktika ne može izvoditi iz epistemologije (Palekčić, 2002, prema Jukić, 2013). Konstruktivistička nastava kao teorijska osnova i kao niz posebnih oblika nastave i učenja nije praktično provediva u svom čistom obliku u školskom učenju. Na temelju nediferenciranog postulata o autonomiji učenja i reaktivitetu svih sadržaja, pristaše konstruktivizma ne mogu udovoljiti velikom dijelu obrazovnih zadaća, odnosno predložiti učinkovite pedagoške mjere glede učinkovitosti prenošenja objektivnog, tradicijama stečenog ljudskog znanja (Palekčić, 2002).

U suvremenoj pedagoškoj paradigmi traži se isključivo opredjeljivanje između aktivnog učenja kao konstruktivistički primjerene metode i poučavanja djece kao tradicionalnog metodičkog pristupa, iako istraživanja kognitivne psihologije ukazuju da tradicionalni principi i metode učenja ne moraju biti inferiorni suvremenima, te se navodi kako neki od njih imaju značajnu korespondenciju s kognitivnim stilovima pojedinaca, pod pretpostavkom da se ne primjenjuju isključivo (Jukić, 2013). Napominje se kako ni jedna metoda, izolirano promatrana, nije dobra ili loša jer njezina primjerenost ovisi o odgojno-obrazovnom cilju i sadržaju (Gojkov, 2015). Umjesto nekritičkog zastupanja ekstremnih gledišta glede primata instrukcije ili konstrukcije, njihov bi odnos trebao postati predmet znanstvenih (teorijskih i praktičnih) didaktičkih istraživanja, i to u kontekstu pedagogijskih teorija obrazovanja i odgoja (Palekčić, 2002). Međutim, dok takvi radovi izostaju, rigidna polariziranja dovode do dihotomiziranja svih didaktičkih pitanja i područja. Djelomičan razlog tomu je i činjenica da se konstruktivističko gledište, u nedostatku vlastite (pedagoške) validacije, može obraniti samo tako da se suprotstavljeno gledište objektivizma i instrukcionizma predstavi u pojednostavljenom, često negativnom, čak karikaturalnom obliku (Palekčić, 2002). Isključivo veličanje konstruktivističkog pristupa u nastavnom procesu može se smatrati novom ortodoksnošću jer je evidentno da unutar ovog pristupa postoje znatna ograničenja (Jukić, 2013). 
Veliki izazov suvremenoj pedagoškoj paradigmi jest i jasno definiranje pojmova odgoja i obrazovanja. Pojedini autori tumače kako cilj školovanja ne može biti odgoj, već samo obrazovanje (Saleci, 1991, prema Šimenc, 2008). Obrazovni ciljevi školovanja koji se neposredno realiziraju kroz izbor nastavnog gradiva, načinom iznošenja građe, ponavljanjem, ispitivanjem, kao popratni produkt imaju odgoj. Drugi autori, pozivajući se na izvornu teoriju pedagogije, navode kako Herbart govoreći o odgojnoj nastavi ističe kako su i izravni odgoj (odgoj koji izbjegava utjecaj preko nastave) i puka nastava (koja prenosi samo informacije) deficijentne forme pedagoške prakse koje pedagogija ne smije prihvatiti (Palekčić, 2010). Nastava o kojoj Herbart govori nije ona iz koje proizlazi puko znanje koje bi čovjeku, s obzirom na to da ne mijenja njegovu narav, moglo ostati i nepoznato. Odgojna je nastava ona koja se sjedinjuje sa samim čovjekom, pa on više ne bi bio isti kada bi mu ta spoznaja bila oduzeta (Mussener, 1988, prema Palekčić, 2010).

Suvremena pedagoška paradigma upućuje na razvoj kompetencija. U kompetencijskom pedagoškom pristupu ističe se značaj ishoda učenja, često uz marginaliziranje važnosti sadržaja kojima se oni ostvaruju. U reformnom konceptu orijentiranom prema kompetencijama sadržaji su promatrani kao sredstvo njihove izgradnje (Palekčić, 2014). Nasuprot tome, ističući važnost pedagoških sadržaja, pojedini autori napominju nužnost razlikovanja obrazovnog i neobrazovnog znanja te razmatraju kakvim se sadržajima istinsko obrazovanje može konstruirati (Komar, 2017). Važnost sadržaja u odgojno-obrazovnom procesu ujedno je istaknuta u razmatranju karakteristika pedagoškog odnosa. U takvom je odnosu učiteljeva zadaća omogućiti dijalog ja-ono, uz istovremeno ostvarivanje dijaloga ja-ti, ja-drugi (Biber, 1999, prema Bašić, 2015). Personalni odnos učenika i učitelja te odnos učitelja i učenika prema predmetu, promatraju se kao dva aspekta istog odnosa (Bašić, 2015). Ipak, u pedagogiji ih je postalo samorazumljivo promatrati kao dva odvojena, paralelna procesa. Tako pojedini autori razjedinjeno govore o učiteljevim pedagoškim i didaktičnim kompetencijama (Jurčić, 2014), što za posljedicu ima odvajanje odgojiteljeve predmetne (stručne) od odnosne (pedagoške) kompetencije (Bašić, 2015).

Postavljasepitanjemoželisuvremenkonceptkompetencijazamijenitishvaćanje odgoja i obrazovanja. Pojedini autori napominju kako obrazovanje i kompetencije nisu podudarni ni komplementarni pojmovi jer slijede sasvim drugačije principe (Komar, 2015). Obrazovanje se određuje kao slobodno djelovanje subjekta koji, uz dijalošku pomoć i posredstvom vlastite interakcije sa sadržajem, a na temelju njihove refleksije, sam sebe mijenja (Komar, 2015). Obrazovanje svoj legitimitet nalazi u ideji spoznaje istine i svim praktično-poetičkim posljedicama, kao i u ideji humaniteta. S druge strane, kompetencija je bitno pragmatička; njezino postojanje 
ovisi o njezinom očitovanju u praktičnoj situaciji. Kompetencija je performativna, pa ne može biti neočitovana, nepragmatična i neučinkovita (Komar, 2015). Uzevši to $\mathrm{u}$ obzir, kompetencija nije ni u kakvoj relaciji spram obrazovanja, ona ga ne dopunjuje, ne proširuje i ne korigira (Komar, 2015).

Obrazovanje hrvatskog i europskog odgojitelja bazira se na razradi njihovog kompetencijskog profila. Navodi se kako je važno razumjeti ključne kompetencije koje učenik razvija u odgojno-obrazovnom procesu kako bi uspješno odgovorio na izazove suvremenog društva znanja i promjena jer je upravo popis tih kompetencija ključan u razumijevanju kompetencijskog profila učitelja (Lončarić, Pejić-Papak, 2009). Istaknute kompetencije koje bi odgojitelji trebali razvijati cjeloživotnim učenjem su suradnja sa sustručnjacima, rad sa znanjem, tehnologijom i informacijama, rad u društvenom kontekstu (Common European Principles for Teacher Competences and Qualifications, 2005). Kao jedna od istaknutih odgojiteljevih kompetencija presudna za odgojiteljev osobni i profesionalni razvoj, izdvaja se i otvorenost za promjene (Bijeli dokument o obrazovanju, 1995, prema Horvat, Lapat, 2012). Nasuprot tome, pojedini autori napominju kako se govori o potrebi izobrazbe nastavnika orijentirane prema izgradnji kompetencija bez dovoljne teorijske utemeljenosti i empirijske provjerljivosti (Palekčić, 2014). Tako, dok se problematizira kompetencijski pristup obrazovanju, istovremeno se na njemu usustavlja obrazovanje, kako suvremenog odgojitelja, tako i djeteta.

\section{INICIJALNO OBRAZOVANJE SUVREMENOG ODGOJITELJA}

Uz navedene izazove pred pedagogijom kao znanosti, a time i nedorečenosti postavljene pred pedagošku praksu, autori zamjećuju neke specifičnosti aktualnog obrazovanja odgojitelja. Budući učitelji sve se više pripremaju za poučavanje u nastavnom procesu, a manje za odgoj u užem smislu (Jurčić, 2014). Evidentira se slabljenje odgojnog djelovanja učitelja u školi, a primjećuje se kako je razlog tome moguće sagledati u načinu pripreme budućih nastavnika tijekom njihovog obrazovanja na pedagoškim fakultetima (Jurčić, 2014). S obzirom na nedovoljno definiranje i promišljanje pojmova odgoja i obrazovanja te nerazumijevanje svrhe odgoja, odnosno s obzirom na to da se temi odgoja ne pristupa razložno (Polić, 2015), navedeno je dijelom očekivano.

Postojeća su zalaganja za obrazovanje odgojitelja koje nije specijalizirano kroz pojedine discipline, metodike pojedinih područja, već se usmjerava na odgojiteljevo razumijevanje procesa učenja i poučavanja uz konstruiranje znanja u interaktivnom procesu (Šagud, 2011). Takav pristup proizlazi iz 
konstruktivističkog koncepta pedagoške paradigme koji je, kako je prethodno navedeno, problematiziran.

Pojedini autori napominju kako u formalnom obrazovanju odgojitelja, na studijima predškolskog odgoja, koncept vezan uz akcijska istraživanja nije dostatno zastupljen, iako se od praktičara očekuje osposobljenost za njihovu provedbu (Visković, 2013). Naglašava se kako uloga učitelja kao akcijskih istraživača nije dovoljno cijenjena i poticana kako u pripremanju studenata učiteljskih fakulteta, tako i u stručnom usavršavanju zaposlenih učitelja (Bognar, 2001). Neki autori tvrde kako je učiteljima u provedbi akcijskog istraživanja potrebna podrška osoba koje u dovoljnoj mjeri poznaju njegov proces, a to mogu biti pedagozi, savjetnici, iskusni učitelji ili sveučilišni profesori (Bognar, 2011). Pri tome oni nisu samo eksperti zaduženi za podučavanje praktičara u ostvarivanju promjena, već su i oni sami angažirani oko procesa edukacije drugih članova zajednice učenja (Bognar, 2011). No, postavlja se pitanje zašto učitelji u dovoljnoj mjeri ne poznaju strukturu akcijskih istraživanja, pa ih eksperti trebaju poučavati instrumentu razvoja njihove djelatnosti. Nasreću, aktualnim obrazovanjem odgojitelja, primijećeni nedostaci nastoje se nadvladati. Suvremeni pedagoški praktičari, tijekom svog obrazovanja na hrvatskim diplomskim studijima ranog i predškolskog odgoja i obrazovanja, upoznaju se sa sadržajima kolegija koji im omogućuju razvoj kompetencija potrebnih za osmišljavanje i provedbu istraživanja u odgojno-obrazovnoj praksi (Vujičić, Čamber Tambolaš, 2017).

Odgojiteljev razvoj znanja, sposobnostii vještina tijekom njihove profesionalne karijere treba biti omogućen raznim formama stručnog usavršavanja. Nepoželjna je tvrdnja kako su odgojitelji često zakinuti za spoznaje prezentirane na znanstvenostručnim skupovima, što je i značajan razlog njihove ograničene transmisije u pedagošku praksu (Sekulić-Majurec, 2007). Društvo pred suvremene učitelje i odgojitelje često postavlja višestruke zahtjeve uz nedostatno ulaganje u njihov profesionalni razvoj i radne uvjete (Jukić, Reić-Ercegovac, 2008).

Autori utvrđuju kako inicijalno obrazovanje odgojitelja treba biti komplementarno s njegovim kasnijim profesionalnim razvojem sukladno aktualnim društvenim, političkim, socijalnim, ekonomskim i drugim determinantama koje impliciraju profesionalne i osobne kompetencije praktičara (Šagud, 2011). Međutim, veoma je značajno napomenuti prethodno neistaknutu znanstvenu odrednicu koja bi trebala usmjeravati odgojiteljevo obrazovanje i daljnji profesionalni napredak. Njegovo djelovanje ne može biti samo politički, socijalno, ekonomski i gospodarski utemeljeno, već upravo pedagogijski zasnovano. Raznim dokumentima kojima se regulira obrazovanje učitelja na razini Europske unije napominje se kako njihovo obrazovanje treba objedinjavati široku bazu znanstveno 
utemeljenih spoznaja o učenju i poučavanju, istraživačku metodologiju te bogat repertoar empirijski provjerenih postupaka kojima se potiču procesi učenja i poučavanja (Vizek-Vidović i sur., 2005). Upravo je zbog toga problematično smatranje kako se konstruktivizam kao psihološka teorija pedagoški prisvaja kao nova paradigma bez dovoljne teorijske razrađenosti i empirijske validacije. Ujedno, diskutabilno je da odgojno-obrazovni sustav svoje ciljeve dominantno izdvaja iz gospodarskih ili ekonomskih potreba društva, odnosno da se suvremeno obrazovanje smatra instrumentom budućeg gospodarskog napretka.

Suvremeni koncept odgojiteljevog obrazovanja detaljno se izlaže dokumentom Standardi kvalifikacija i unapređivanje kvalitete studijskih programa odgojitelja i učitelja (2016). S obzirom na to da se Strategijom obrazovanja znanosti i tehnologije iz 2014. godine navodi kako u Hrvatskoj ne postoji detaljna analiza i prijedlozi o sadržaju temeljnih zanimanja i potrebnih kompetencija odgojitelja, učitelja, nastavnika, ravnatelja, savjetnika, mentora i trenera, ovim dokumentom započinje tražena razrada. Navodi se kako se dokument Standardi kvalifikacija $i$ unapređivanje kvalitete studijskih programa odgojitelja $i$ učitelja (2016) zasniva na Hrvatskom kvalifikacijskim okviru (2009). Kvalifikacijski okvir (2009) predstavlja instrument kojim se uređuje cjelokupan sustav kvalifikacija na svim obrazovnim razinama kroz standarde utemeljene na ishodima učenja, a usklađene s potrebama tržišta rada, pojedinca i društva u cjelini. Ističe se kako dokument Standardi kvalifikacija i unapređivanje kvalitete studijskih programa odgojitelja i učitelja (2016) implicira hrvatsku obrazovnu tradiciju, obuhvaća aktualno stanje i potrebe razvoja gospodarstva, pojedinca i društva u cjelini. Ipak, upitno je uvažavanje hrvatske obrazovne tradicije s obzirom na to da se zasniva na konceptu kompetencija koji ne proizlazi iz tradicije hrvatskog pristupa obrazovanju.

Tuning projektom (2000) definiraju se ishodi učiteljevog obrazovanja, opisani kroz razine kompetencija koje se obrazovanjem mogu postići (Uvod $u$ projekt Uskladivanje obrazovnih struktura u Europi, 2006). Kriteriji razlikovanja pojedinih stupnjeva visokog obrazovanja izražavaju se Dublinskim deskriptorima kroz konkretno navođenje ishoda učenja na preddiplomskoj, diplomskoj i poslijediplomskoj razini (Vlahović-Štetić, Kamenov, 2016). Priručnikom Standardi kvalifikacija $i$ unapređivanje kvalitete studijskih programa odgajatelja $i$ učitelja (2016) sve je navedeno primijenjeno na kompetencije odgojitelja i ishode vezane uz studijski program obrazovanja odgojitelja na razini odgojitelja prvostupnika te magistra ranog i predškolskog odgoja i obrazovanja. Iako je navedena sveobuhvatna pažnja odgojiteljevom obrazovanju nužna, i unatoč tome što se ovim dokumentom čini izrazito važan doprinos u promišljanju odgojiteljevog obrazovanja, još uvijek se opravdano problematizira izdvajanje kompetencija kao supstituta koncepta 
obrazovanja. Ipak, navedeni je dokument značajan doprinos daljnjoj razradi i razmatranju najboljih rješenja za strukturiranje predloška obrazovanja odgojitelja.

\section{ZAKLJUČAK}

Opisujući kompetencije odgojitelja i odgojitelja-stručnog suradnika, dokumentom Standardi kvalifikacija i unapredivanje kvalitete studijskih programa odgajatelja i učitelja (2016), navodi se kako je njihova uloga praktično primijeniti najnovije znanstvene spoznaje o razvoju i učenju djeteta. Ipak, kako se u nastavku dokumenta izriče, uloga autonomnog odgojitelja nije samo primjenjivati, već kritički razmatrati spoznaje, evaluirati ih te potencijalno stvarati nove. Važno je isticanje potrebe odgojiteljevog sudjelovanja $u$ istraživanjima i inovacijama. No, pojedini autori tvrde kako se uloga akcijskog istraživača, najčešće pedagoga ili vanjskog suradnika ustanove $\mathrm{u}$ razvoju prakse odgojitelja može poistovjetiti $\mathrm{s}$ ulogom odgojitelja prema djetetu - kao što je odgojitelj pomagač i voditelj djeteta u odgojno-obrazovnom procesu, tako je istraživač pomagač i voditelj odgojitelju u istraživanju odgojno-obrazovne prakse (Miljak, 1996). Tvrdi se da je stav kako učitelji lako mogu preuzeti ulogu kritičkog prijatelja i akcijskog istraživača, nerealno očekivanje (Bognar, 2011). Suvremeni odgojitelji kao pedagoški praktičari trebaju poticati redefiniranje prethodnih stavova, a tome znatno može doprinijeti osmišljavanje njihovog obrazovanja koje će potaknuti razvoj istraživački orijentiranih, kreativnih i kritički promišljajućih stručnjaka.

Pojedini autori (poput Keeley, 2009) suvremenog pojedinca učestalo reducirano svode na ljudski kapital upućen gospodarskom probitku određene zajednice. Strategijom obrazovanja, znanosti i tehnologije (2014) napominje se kako je i u Hrvatskoj, po uzoru na razvijena društva gdje su ljudski potencijali temelj gospodarske uspješnosti i društvenog napretka, nužno graditi sustav kojim će se smišljeno otkrivati, njegovati, usmjeravati i poticati individualni potencijali i sposobnosti. Navedenim se dokumentom navodi kako je upravo središnja misija sustava odgoja i obrazovanja prepoznavanje talenata i pružanje odgovarajuće podrške za rast i razvoj svakog pojedinca. Upućuje se na važnost otkrivanja, razvoja i upravljanja ljudskim potencijalima od najranije dobi, pri čemu posebna pozornost treba biti upućena darovitim pojedincima (Strategija obrazovanja, znanosti, $i$ tehnologije, 2014). Deklaracijom o znanju (2004) naglašava se kako se Hrvatska znanjem treba izvući iz kruga slabije razvijenih zemalja i spriječiti tehnološku zaostalost. Nadalje, navodi se kako razlike u znanju i njegovoj tehnološkoj primjeni postaju glavni čimbenici koji dijele razvijene zemlje od nerazvijenih, bogate od siromašnih, visoki životni standard od niskog. Iz tog razloga gospodarsko- 
ekonomski sektor pozornost usmjerava $\mathrm{k}$ obrazovanju. No, iz pedagogijske perspektive promatrano, država koja obrazovanje vidi kao pragmatičnu korist, kao funkciju reprodukcije svojih formi, funkciju tržišta rada i heteronomnih potreba kapitalističke proizvodnje i potrošnje, u neskladu je s obrazovanjem promišljanim iz vlastitog pojma (Komar, 2009). Ukoliko prihvatimo čovjeka kao biće kojem je obrazovanje nužno pripadno jer svoju slobodu samoodređuje znanjem (Komar, 2008); ukoliko uvažimo njegovu upućenost učenju i odgojivosti (Polić, 2015), tada je navedeni društveno propagiran pristup odgoju i obrazovanju - manipulativan. Iako je uvažavanje konteksta u kojem se odgoj i obrazovanje provode važno, pedagogijsko preuzimanje gospodarsko-ekonomskih nastojanja, bez vlastite razrade ciljeva i svrhe odgoja i obrazovanja, veoma je dvojbeno.

Obrazovanje i stručno djelovanje odgojno-obrazovnog kadra potrebno je temeljiti na autentičnim spoznajama pedagogijske znanosti. I dosege srodnih znanstvenih disciplina, poput psihologije, pedagogija ne bi trebala (samo) asimilirati, već ih prilagoditi vlastitom specifičnom predmetu.

Iz navedenog proizlazi evidentna važnost kontinuiranog razmatranja razvoja pedagogije kao znanosti, obrazovanja odgojitelja kao pedagoških stručnjaka te društva kao zajednice. Praćenje navedenog nužno je radi etabliranja pedagogije, emancipiranja pedagoške djelatnosti te profesionalizacije suvremenih odgojitelja kao pedagoških praktičara. 


\section{LITERATURA}

1. Babić, N., Irović, S., Krstović, J. (1997). Vrijednosni sustav odraslih, odgojna praksa i razvojni učinci. Društvena istraživanja, 6 (4-5): 551-575.

2. Baran, J., Dobrotić, I., Matković, T. (2011). Razvoj institucionalnog predškolskog odgoja u Hrvatskoj: promjene paradigme ili ovisnost o prijeđenom putu. Napredak: časopis za interdisciplinarna istraživanja u odgoju i obrazovanju, 152 (3-4): 521-540.

3. Baran, J. (2013). Predškolski odgoj i obrazovanje kao socijalna investicija. Revija za socijalnu politiku, 20 (1): 43-62.

4. Bašić, S. (2015). Svrha i osnovna obilježja pedagoškog odnosa. U: S. Opić, V. Bilić, M. Jurčić (ur.), Odgoj u školi (11-45). Zagreb: Učiteljski fakultet Sveučilišta u Zagrebu.

5. Bognar, B. (2001). Kritičko-emancipacijski pristup akcijskim istraživanjima. Život i škola časopis za teoriju i praksu odgoja i obrazovanja, 47 (6): 45-60.

6. Bognar, B. (2011). Problemi u ostvarivanju suštinskih promjena u praksi posredstvom akcijski istraživanja. U: D. Kovačević, R. Ozorlić-Dominić (ur.), Akcijsko istraživanje i profesionalni razvoj učitelja i nastavnika (41-60). Zagreb: Agencija za odgoj i obrazovanje.

7. European Comission: Education and Culture. (2005). Common European Principles for Teacher Competencies and Qualifications. S mreže preuzeto 3. travnja 2020. sa: http://www.pef.uni-lj.si/ bologna/dokumenti/eu-common-princcciples.pdf

8. Gojkov, G., Stojanović, A. (2015). Didaktičke kompetencije i Evropski kvalifikacioni okvir. Beograd: Srpska akademija obrazovanja.

9. Horvat, A., Lapat, G. (2012). Cjeloživotno obrazovanje učitelja. Andragoški glasnik, 16 (2): 131142 .

10. Hrvatski kvalifikacijski okvir (2009). S mreže preuzeto 21. listopada 2020. s: http://www.azvo.hr/ images/stories/HKO_Priručnik.pdf

11. Jukić, R. (2013). Konstruktivizam kao poveznica poučavanja sadržaja prirodoznanstvenih i društvenih predmeta. Pedagogijska istraživanja, 10 (2): 241-263.

12. Jukić, T., Reić-Ercegovac, I. (2008). Zanimanja učitelja i odgajatelja iz perspektive studenata. Metodički obzori, 3 (2): 73-82.

13. Jurčić, M. (2014). Kompetentnost nastavnika - pedagoške i didaktičke dimenzije. Pedagogijska istraživanja, 11 (1): 77-91.

14. Keeley, B. (2009). Ljudski kapital: od predškolskog odgoja do cjeloživotnog učenja. Zagreb: Educa.

15. Kolak, A. (2015). Odgojni problemi u suvremenoj školi. U: S. Opić, V. Bilić, M. Jurčić (ur.), Odgoj u školi (155-176). Zagreb: Učiteljski fakultet Sveučilišta u Zagrebu.

16. Komar, Z. (2008). Pedagogija kao sustavna znanost obrazovanja. Pedagogijska istraživanja, 5 (2): $27-138$.

17. Komar, Z. (2009). Slobodno vrijeme kao vrijeme istinskog obrazovanja. Filozofska istraživanja, 114 (29): 297-302.

18. Komar, Z. (2015). Mogućnost odgoja i obrazovanja u kontekstu postmodernog pojma znanja. U: S. Opić, V. Bilić, M. Jurčić (ur.), Odgoj u školi (223-250). Zagreb: Učiteljski fakultet Sveučilišta u Zagrebu. 
19. Komar, Z. (2017). Svrhovitost odgoja, obrazovanja i njezino jedinstvo s idejom čovjeka kao ono utemeljujuće pedagogijske znanosti. Radovi Zavoda za znanstvenoistraživački i umjetnički rad u Bjelovaru, 11: 47-60.

20. Krstović, J., Vujičić, L., Pejić Papak, P. (2016). Standardi kvalifikacija i unapređivanje kvalitete studijskih programa odgojitelja i učitelja. Rijeka: Učiteljski fakultet Sveučilišta u Rijeci.

21. Lončarić, D., Pejić Papak, P. (2009). Profiliranje učiteljskih kompetencija. Odgojne znanosti, 11 (2): 479-497.

22. Mendeš, B. (2018). Profesionalno obrazovanje odgojitelja predškolske djece: od jednogodišnjeg tečaja do sveučilišnog studija. Zagreb: Golden marketing - Tehnička knjiga.

23. Milat, J. (2007). Epistemologija pedagogije: dileme, pitanja, moguća rješenja. Pedagogijska istraživanja, 4 (2): 189-199.

24. Miljak, A. (1996). Humanistički pristup teoriji i praksi predškolskog odgoja. Velika Gorica: Persona.

25. Mlinarević, V. (2000). Kompetencija odgojitelja i autonomija djeteta. U: N. Babić, J. Krstović (ur.), Interakcija odrasli-dijete i autonomija djeteta, Osijek, 2000 (143-150). Osijek: Visoka učiteljska škola.

26. Palekčić, M. (2002). Konstruktivizam-nova paradigma u pedagogiji?. Napredak, 143 (4): 403-413.

27. Palekčić, M. (2010). Herbartova teorija odgojne nastave - izvorna pedagogijska paradigma. Pedagogijska istraživanja, 7 (2): 319-338.

28. Palekčić, M. (2013). Kultiviranje teorijskog mišljenja - uvjet identiteta i znanstvenog statusa pedagogije. U: N. Hrvatić, A. Klapan (ur.), Pedagogija i kultura (324-334) ). Zagreb: Hrvatsko pedagogijsko društvo.

29. Palekčić, M. (2014). Kompetencije i nastava:obrazovno-politička i pedagogijska teorijska perspektiva. Pedagogijska istraživanja, 11 (1): 7-24.

30. Pastuović, N., et. al. (2004). Deklaracija o znanju : Hrvatska temeljena na znanju i primjeni znanja. Zagreb: HAZU.

31. Polić, M. (2015). Razložnost odgoja. Metodički ogledi, 22 (2): 165-188.

32. Sekulić-Majurec, A. (2007). Kraj rata paradigmi pedagoških istraživanja. Pedagogijska istraživanja, 4 (2): 203-214.

33. Slunjski, E., Šagud, M., Brajša-Žganec, A. (2006). Kompetencije odgojitelja u vrtiću - organizaciji koja uči. Pedagogijska istraživanja, 3 (1): 45-58.

34. Slunjski, E. (2016). Izvan okvira 2: promjena. Zagreb: Element.

35. Slunjski, E. (2011). Kurikulum ranog odgoja - istraživanje i konstrukcija. Zagreb: Školska knjiga.

36. Strategija obrazovanja, znanosti i tehnologije. (2014). S mreže preuzeto 9. rujna 2020. s: http:// www.kvalifikacije.hr/sites/default/files/news/2018-01/Nacrt-prijedloga-strategije-obrazovanjaznanosti-i-tehnologije.pdf

37. Šagud, M. (2011). Inicijalno obrazovanje odgajatelja i profesionalni razvoj. Pedagogijska istraživanja, 8 (2): 259-267.

38. Šimenc, M. (2008). Znanje kao bitni popratni proizvod istraživačke zajednice, Metodički ogledi, $15(1): 47-59$ 
39. Visković, I. (2013). Akcijska istraživanja u funkciji razvoja institucionalnog predškolskog odgoja i obrazovanja. Educa, 6 (6): 67-76.

40. Vlahović_Štetić, V., Kameov, Ž. (2016). Kako ostvariti željene ishode u studijskim programima priručnik za sveučilišne nastavnike. Zagreb: Filozofski fakultet Sveučilišta u Zagrebu.

41. Vujičić, L. Čamber, Tambolaš, A. (2017). Profesionalan razvoj odgojitelja - izazov za pedagoga. U: M. Turk (ur.), Suvremeni izazovi u radu (školskog pedagoga) (132-155). Rijeka: Filozofski fakultet u Rijeci.

42. Tischler, D. (2007). Autonomija učitelja i njihov profesionalni razvoj. Pedagogijska istraživanja, 4 (2): 293-298. 


\title{
CONTEMPORARY EDUCATOR AS A PEDAGOGICAL PRACTITIONER
}

\begin{abstract}
In understanding an educator as a pedagogical practitioner, it is necessary to start from the consideration of the modern status of pedagogy as a science, given the assumption that it is the foundation for directing educators' educational and practical activities. The paper considers the current status of educational workers in institutions of early and preschool education and the professional requirements that are set before them. Reference is made to the scientific (in)autonomy of pedagogy. The paper also emphasizes the role of educators in the development of the educational system of preschool education. Based on understanding the current position of pedagogy and requirements addressed to professionals in preschool institutions, the paper considers the concept of initial education of early and preschool children and its adequacy in relation to the professional profile of modern educators, and the need to affirm their pedagogical activity.
\end{abstract}

Keywords: educator of early and preschool children, pedagogical practitioner, modern institutions of early and preschool education. 